\title{
Teachers' strategies in digital and flexible online studies
}

\author{
Synnøve Thomassen Andersen \\ $\mathrm{PhD}$ \\ The Arctic University of Norway, Alta, Norway \\ synnove.thomassen.andersen@uit.no
}

\begin{abstract}
The aim of this paper is to highlight how the teachers learning strategies influence students learning outcome. Based on qualitative research we describe a digital online study-project. The results shows that teachers' strategies highly influence students learning outcome. Communication and interaction by use of technology became a key element in the students own learning process. The teachers strategy related to use of technology made the student active include the social and professional environment in their learning process, which contributed to their own competence.
\end{abstract}

Keywords: digital, flexible, technology, learning processes, communication

\section{Introduction}

This paper aims to explore in which way to organize relevant online study for students, based on learning strategies. More specifically, the focus is on the teachers' own learning strategies when planning and organizing online studies.

The world is becoming digital and universities offers updated and relevant education that motivates students learning and use of technology. Online studies have becoming a common form of study all over the world today. In most countries, there is a need to provide lifelong learning, which requires that the learning activities offered are best suited to the students' needs and prerequisites. To realize this, the students themselves, must be able to determine the time, place and progression and working methods largely. However, digitalization has also resulted in a number of challenges [1]. The research question in this paper is; how to organize online study based on the teachers learning strategies, so that the students can get optimal learning outcome? The study program described here is Information Technology in Health Care Services.

\section{Theoretical frame}

There are many good examples of online learning activities and assessments methods ${ }^{1}$. NOKUT claim that the use of ICT and digital learning in higher education

\footnotetext{
${ }^{1}$ https://utdanningsforskning.no/
} 
is a tool for raising the quality of education, focusing especially on the students' learning outcomes. Learning is central, and thoughts and behaviors aimed at obtaining, processing and organizing new material are defines as good learning strategies. Teachers has to include these factors systematic within their own planning of teaching. However, principles of collaborative learning are important for establishing good learning strategies [2].This include acquiring learning strategies and interest in learning, participate a committed community, get to work, enable opportunities in a constructive manner. Collaborating, coordinating and trusting each other is important to include in studies as factors for teachers, in order for the students to learn something for themselves. Such socio-cultural learning bases on theories by emphasizing that learning takes place in a social context and not in a vacuum [3].

Teacher has to be aware that students can have more control over how they learn, and centered on what they should learn when using technology [4]. However, students need to prepare for online learning to get a better learning effect [1]. One way to do this is use of flipped classroom. Flipped classroom or inverted classroom, is about moving the theoretical learning out of the classroom and the practical learning into the classroom [2].The principle is that the lecture takes place on video (tutorials) that the students look at home as a lesson, while school time is being used for processing and to communicate about the substance. When students have interest in the subject from the beginning, they will be more motivated to do what is needed to achieve the academic goals. Research [2] highlight that students need to develop their own approaches and ways to solve problems demanding the learning environment where they have time and space to reflect on their own learning process. Further, students must have access to several ways to interact with content outside the classroom. Then they can choose the learning strategy that best suits them and thus increase learning outcomes [2]. Three important factors in organizing these online studies were:

- Give the students the chance to use the most appropriate learning strategy.

- When introducing new subject matter, progression should be carefully structure and efforts must be made to make sense.

- Allow students to reflect on their own learning processes together with other students through a review of each other.

Teachers' must offer a broad teaching repertoire where their own digital skills often becomes critical related to the students' learning outcomes in the digital learning processes, which are used ${ }^{2}$.

\section{Methodology in the Research}

This online study project follows the interpretative and qualitative tradition in pedagogical and information systems research [5, 6]. Qualitative method is

${ }^{2}$ https://utdanningsforskning.no/artikler/utdanningsledelse-og-digitale-laringsformer-i-hoyereutdanning/ 
characterized by direct contact between the researcher and those studied [7, 8]. The empirical data, were collected in the form of interviews with teachers and observation of students. The data collection followed the progress of the study project, since the start in 2013. Data from the teachers, was collected through interviews.

Observation is another important source of data, especially through students online study program. The study also includes analysis of significant amounts of archival data including notes and documentation related to planning and organizing the study.The survey was conducted mainly based on observation of the students during online teaching and teacher supervision. Interpretation is therefore of particular importance. All the students were both students and full time workers, where everyone combined the online study next to their daily work, family and other commitments. The research include dialogue and participation in an active and inclusive learning environment.

\subsection{The case; Information Technology in Health Care Services}

UiT, The Arctic University of Norway, (UiT in Alta), offered during the period 20132015, an online study program to acquire knowledge and competence in eHealth, named Information Technology in Health Care Services, 30 ECTS credits. The program offered no degree, but considered as part of the MBA. The study aimed at employees in the health and care sector and was an offer in further education.

The admission requirement was that applicants had a bachelor degree in health and social studies or equivalent education. Applicants with different backgrounds and/or practices from the health and care services were considered individually. The study included observation of 30 students in 2013, 25 students in 2014 and 15 students in 2015. In total 60 students completed the study.

The study intended for personnel in health and care services who wish to expand and/or update their ICT skills so that they could use the technology in a safe and efficient way, as well as help to exploit the potential of the technology. The teachers planned the study to cover a number of current topics:

o Premises for ICT in health and care services, health policy objectives, laws and regulations.

o Principles for the treatment of patient information and an understanding of the requirements and rules that were set.

o Ethical and legal issues related to information management in the health and care services.

o Practical solutions to the requirements imposed on users of electronic patient information focusing on electronic patient records.

o Overview of system solutions that were implemented at health institutions focusing on electronic patient records.

o Creation of specific knowledge and skills in system solutions that were used. How to utilize ICT as a tool in your own work situation. Knowledge of change and decision making in the workplace to become an active participant in organizational development.

o Project management and project work. 
The teachers structured the theme in the first semester like this: project work, eHealth, health policy, laws and regulations. The second semester included privacy, information security and information quality. The planning was based on the expected learning outcome for the students.

\subsection{Planning of the learning outcomes}

The teacher planned and divided the students' learning outcomes into three different subjects. The argument was that this made it easier to give the students formative and summative assessments in the end of the study.

1) Objectives related to knowledge:

Here, the aim was that the students should be able to account for the premises for ICT in the health service, health policy objectives, laws and regulations. Students should also be able to explain the principles for processing patient information and acquire an understanding of the requirements and rules that were set. It was also important to arrange for students to gain knowledge of ethical and legal issues related to information management in the health and care services. Finally yet importantly, a central goal was that the students should acquire an overview of the information system solutions into use at health institutions focusing on electronic patient records.

2) Goals related to skills

Related to this point, the aim was that students should be able to use online information sources and other electronic interaction systems and services. Another goal was that the students should be able to practice the legal and practical aspects of the storage, retrieval and use of digital patient and client information. To achieve this, the goal was for students to be able to utilize ICT as tools in their work. They also had to be able to initiate practical solutions to the demands made on users of electronic patient information focusing on electronic patient records. Finally, it was a goal of students to be able to carry out project management and project work. It was therefore important that they could develop concrete knowledge and skills in how to use information systems solutions.

3) Objective of general competence.

An important goal of overall compatibility was that the students should understand the relationships between ICT, human and organizational development in the health and care services. Furthermore, the students should use ICT to help to be better utilize to improve service provision in the health and care services, by the use of electronic records and telemedicine, as well as improving the service offering in the health and care services. It was important for the teachers that the students should have knowledge of change and decision-making processes at the workplace to become an active player in organizational development at their own workplace after the study.

\section{Analyzing the planning and organizing of the online study}

UiT in Alta used ClassFronter (Fronter) as the communication and learning platform. 
ICT was an important tool in the implementation of the study program. It was used email, Internet, e-meetings and use of communication and learning platforms in teaching and counseling and for disseminating information. ICT was an important tool in communication between students, and between students and teachers.

By analyszing the teachers planning and organization of the online study, we found that the students where offered training in and use of computer services at the start of the study. We found that there were used different learning methods and working methods: Lecture, individual or group supervision, group work, project work, discussion boards, wiki, written assignments, etc. An important goal was to involve the students in the teaching themselves. The teaching was put up so that the students could largely come to understanding and insight through independent work. Primarily, the practical side of ICT was by the teachers handled through experience learning, which meant that students could acquire knowledge and skills through use of data processing tools in solving tasks.

Relevant lectures, was introduced as new knowledge for the students. The lectures had have different forms, for example, be lecture sequences presented online and/or on collection. Certainly as introduction to the theme, presentation of the theme/syllabus and factual lectures. It could also be a document, for example a power-point presentation, optionally combined with audio. Finally, there could be lecture at the e-meeting, that is to say direct/synchronous communication over studio or web camera (or audio only). In order to acquire the necessary knowledge, the student received regular assignments in various subjects related to theory and possibly to practice. The work assignments had varied content according to the topics discussed. In the assignments, students could apply for literature in addition to the curriculum. There was guidance and written/oral feedback on some of the tasks.

The teachers pointed out that group and teamwork was an important work and learning activity. UiT in Alta expected students to participate actively in online groups throughout the entire study program. The students had to accommodate each other's opinions and perspectives, and actively participate in academic discussions and reflections. The group processes should help the students learn how to collaborate, by helping and supporting each other as well as professionally and personally. The teachers was responsible for the group composition in cooperation with the students. There was cooperation between learning partners. A learning partner is another online student, usually in the same geographical area, as the student could digitally discuss specific questions, assignments or other questions. The teachers plan activities in use of digital tools that created good learning situations and a good learning environment. The teachers organized the study characterized by individual freedom and collaboration in a collective network. The different tasks required the student to be active, utilizing the social and professional environment both on campus and online, as well as utilizing the flexibility of the online study to develop own skills. In each subject, the students got both formative and summative assessment. The study program was evaluated annually. It is a prerequisite for many motivation and how they create ownership of their own education, and gradually becoming more conscious learning students who see the connection between their own learning processes and their own learning outcomes [9]. Good communication is a prerequisite for good health and social work, and the ability to communicate can be trained and developed [10]. By utilizing student habits and the use of technology, one 
can facilitate new ways of communicating and learning that can lead to change in their work practices. For example, new opportunities to ensure more student participation. However, use of ICT was important and the students needed more education in order to improve their own skills.

We found that communication and interaction were key elements in the learning process, and students actively use the social and professional environment in the learning process to develop their own skills. Strategies included students the chance to use the most appropriate learning strategy was important. When the teachers introduced new subject, progression was carefully structured and efforts made to make sense.The teachers allowed students to reflect on their own learning processes together with other students through a review of each other.

\section{Concluding remarks}

This article argues that teachers learning strategies highly influence students learning outcome in online studies. Digital and flexible online studies offers great opportunities for teachers to plan and organize the learning objects.

The teachers strategy in use of technology made the student active include the social and professional environment in their own learning process, which contributed to their own competence. Communications and interaction based on technology became a central element in the learning process for the students.

\section{References}

1. Andersen, S. T. ,User-centered innovation in psychiatric healthcare by using mobile technology,(PhD thesis), University of Oslo, Oslo. (2013).

2. Strayer, J.F., The effects of the classroom flip on the learning environment: A comparison of learning activity in a traditional classroom and a flip classroom that used an intelligent tutoring system. The Ohio State University. (2007).

3. Vygotsky, Lev ., Tænkning og sprog. København, (1982).

4. Krokan, A Smart læring: Hvordan IKT og sosiale medier endrer læring? Fagbokforlaget Vigmostad \& Bjørke AS. (2012).

5. Thagaard, Tove. Systematikk og innlevelse. En innføring i kvalitativ metode. 4 utg. Fagbokforlaget. ISBN 9788245014938, (2013).

6. Walsham, G. Doing Interpretive Research. European Journal of Information Systems 15(3) 320-330. (2006).

7. Johannessen A., Tufte P.A, \& Kristoffersen L., Introduksjon til samfunnsvitenskapelig 1 metode. Oslo: Abstrakt forlag, (2004).

8. Kvale, S. og Brinkmann, S., Det kvalitative forskningsintervju, Gyldendal akademisk, Utgave: 2. utg. ISBN: 9788205385290 , Oslo, (2009).

9. Hasle, S. Sammenheng mellom ordforråd og avkodingsferdigheter i teori og forskning. Norsk tidsskrift for logopedi, årgang 59, nr. 2, 6-13. (2013).

10. Eide H og Eide, T., Etikk og kommunikasjon, ISBN 9788204085146, Oslo (2005). 